\title{
PEMANFAATAN PUPUK ORGANIK UNTUK MENINGKATKAN TERHADAP PRODUKSI TANAMAN BANGUN-BANGUN (Coleus amboinicus, Lour)
}

\author{
Debby Syukriani ${ }^{1}$, Nelzi fati ${ }^{1,}{\text { Ramond } \text { Siregar }^{1}}^{1}$ \\ ${ }^{1}$ Politeknik Negeri Payakumbuh \\ email: Nelzifati@gmail.com \\ ${ }^{2}$ Politeknik Negeri Payakumbuh \\ email: syukrianidebby@yahoo.co.id
}

\begin{abstract}
Science and technology for the Community Activities Program ( IbM ) of organic fertilizer / compost on plants wake up has been conducted in a herd Permato mudo villages and natural ox Silaing porch in the village below, the Western District of Padang Panjang, Municipality of Leopold. This activity aims to increase the milk production of dairy cows through the use of the leaves in the wake lick candy. The benefits of this activity is to assist farmers in improving milk production of dairy cows per day, so that milk production can be increased which increased revenue. To achieve the goal of community services mentioned above, it has been done lectures , live demonstrations on planting crops wake (Coleus amboinicus, Lour ) which uses organic fertilizer produced . Area is used as a demonstration plot is $2500 \mathrm{~m} 2$ with planting distance is $30 \times 40 \mathrm{~cm}$, with NPK fertilizer $550 \mathrm{~kg}$ / ha of organic manure $10 \mathrm{t} / \mathrm{ha}$ of organic fertilizer and 12 tons / ha. The evaluation shows that the high activity of plant organic fertilizers 12 tonnes / ha higher than NPK fertilizer with organic manure 10 tonnes / ha .

Of service activities can be concluded that the use of compost $12 \mathrm{~kg} / \mathrm{ha}$ can increase crop production and high wake than that of compost 10 tons / ha with NPK fertilizer.
\end{abstract}

Keywords : Production plants wake up, organic fertilizer, NPK

\section{PENDAHULUAN}

Tanaman torbangun (Coleus amboinicus Lour) merupakan spesies terbesar dari tanaman Family Lamiaceae yang digunakan dalam pengobatan. Tanaman torbangun dikenal sebagai tanaman obat di kalangan suku Batak Provinsi Sumatera Utara yang mengandung serat tinggi, terutama serat larut air, disamping itu tanaman ini banyak tumbuh dan berkembang di daerah Sumatera Utara, dan telah banyak dikonsumsi sebagai sayuran oleh ibu-ibu yang baru melahirkan untuk meningkatkan produksi air susu. Di samping itu dari berbagai informasi diketahui bahwa selain daun katuk, jenis tanaman lain yang dapat digunakan dapat meningkatkan produksi susu adalah daun bangun-bangun (Depkes, 2005). Lawrence et al. (2005) menyatakan bahwa dalam tanaman daun bangun-bangun (Coleus amboinicus, Lour) ditemukan tiga komponen utama yang berkhasiat, yaitu komponen farmakoseutika. Hal ini telah dibuktikan melalui beberapa penelitian, diantaranya Silitonga (1993) yang mendapatkan bahwa terjadi peningkatan produksi susu sampai $30 \%$ pada tikus putih dan pertumbuhan anak lebih baik. Lebih lanjut dari penelitian Santosa (2001), memperlihatkan peningkatan produksi air susu ibu sampai dengan $47,7 \%$ pada ibu yang menyusui dan pertambahan bobot badan bayi lebih tinggi. Damanik et al. (2006), menunjukkan bahwa pada ibu melahirkan, konsumsi daun bangunbangun membantu mengontrol post partum bleeding dan berperan sebagai uterine cleasing agent, sedangkan pada ibu menyusui, konsumsi daun bangun-bangun dapat menstimulir produksi susu tanpa efek merugikan. Lebih lanjut Damanik et al. (2006) menyatakan pada ibu yang menyusui, konsumsi daun bangun-bangun meningkatkan produksi susu ASI sebesar 65\% dan lebih tinggi dibandingkan dengan kontrol maupun ibu yang menyusui yang mengkonsumsi fenugreek capsule, yang hanya meningkatkan produksi ASI sebesar 20\%. Dari hasil penelitian Rumetor (2008), suplementasi daun bangun-bangun dan Zinc vitamin E dapat meningkatkan produksi susu kambing PE sebesar $67,22 \%, 88,46 \%$ dan $98,65 \%$ pada setiap level penggunaan daun bangun-bangun 3-9 gr per $\mathrm{kg}$ dari bobot badan. Ternak di Indonesia biasanya diberi hijauan rumput maupun limbah pertanian yang hanya dititik beratkan pada pemenuhan protein dan energi (zat gizi makro), sedangkan zat gizi mikro kurang diperhatikan. Torbangun selain kaya akan serat juga kaya akan kandungan zat gizi mikro seperti magnesium, besi, zink, kalsium, $\alpha$-tocopherol dan $\beta$-karoten. Selain itu juga 
mengandung minyak atsiri antara lain fenol, karvakrol, isopropyl okresol dan sinerol serta zat aktif seperti flavonoid dan glikosida yang berguna sebagai antioksidan (Batubara, 2004). Secara visual produksi dan reproduksi ternak akan tidak normal bahkan timbul gejala klinis walaupun bahan makanan yang diberikan cukup banyak jika zat gizi mikronya tidak seimbang terutama kurangnya $\mathrm{Zn}$. Mineral Zn berfungsi sebagai kofakto dari banyak enzim metabolism (Tarmidi, 2011). Namun ketersediaannya pada pakan hijauan kurang (Piliang, 2000). Selanjutnya Hartadi et al. (1995) melaporkan bahwa kandungan $\mathrm{Zn}$ dalam hijauan pakan ruminansia di Indonesia hanya berkisar 13-32 mg/kg bahan kering. Jika mengacu konsumsi ternak ruminansia 3\% bahan kering per hari maka ternak memperoleh asupan $\mathrm{Zn}$ sebesar 0,84 - 1,26 mg/kg bahan kering/hari. Nilai ini masih jauh dari rekomendasi NRC yang dikemukakan Buchanan-Smith et al. (2009) kebutuhan Zn ternak ruminansia $40 \mathrm{mg} / \mathrm{kg}$ bahan kering/hari. Tanaman bangun-bangun tersebar di dataran rendah sampai dataran tinggi, namun informasi produksi hijauan masih terbatas terutama respon pemupukan organik terhadap tanaman bangun-bangun (Coleus amboinicus, Lour ) tersebut, guna mendapatkan produksi yang optimal.

Disamping itu untuk mendapatkan produksi daun bangun-bangun yang optimal, tidak terlepas pemupukan baik jenis maupun jumlah pupuk yang diberikan pada tanaman tersebut. Jenis pupuk yang diberikan bisa berasal pupuk buatan maupun pupuk organik, akan tetapi pada saat sekarang harga pupuk semakin mahal ditambah lagi peternak bersaing dengan petani untuk mendapatkan pupuk buatan tersebut. Kartini (2000) cit Siregar et al. (2013) menyatakan penggunaan pupuk kimia secara terus menerus dalam jumlah banyak merupakan salah satu penyebab penurunan kualitas lahan (degradasi lahan) pertanian. Pemakaian pupuk buatan oleh petani di Indonesia nampak meningkat sangat dominan untuk meningkatkan hasil pertanian secara nyata dan cepat. Sebaliknya petani hampir melupakan peranan pupuk organik karena responnya lambat. Hal ini berakibat kurang baik bagi perbaikan sifat fisik, kimia dan biologi tanah. Untuk mengembalikan unsur hara tersebut maka pemakaian pupuk organik saat sekarang sangat dianjurkan untuk memperbaiki tingkat kesuburan tanah. Kompos berasal dari kotoran sapi, yang merupakan hasil sampingan dari beternak sapi perah. Satu ekor sapi dewasa dapat menghasilkan 10 $\mathrm{kg} / \mathrm{hari}$ kotoran sapi. Kotoran sapi yang dihasilkan oleh peternak sapi perah belum dimanfaatkan dan biasanya dibuang ke sungai. Sudono et al. (2003) menyatakan bahwa limbah sapi dapat dijadikan kompos atau pupuk organik yang pada saat sekarang sedang diminati masyarakat, ditambah lagi daerah Padang Panjang sebagian besar mata pencahariannya adalah bertani.

Dalam manajemen bubidaya ternak, pakan merupakan kebutuhan tertinggi, yaitu $60 \%$ dari seluruh biaya produksi, mengingat tingginya komponen biaya tersebut, maka perlu adanya perhatian dalam penyediaan pakan baik dari segi kualitas maupun kuantitas. Dari hasil penelitian Heriyatno (2009), faktor-faktor yang mempengaruhi produksi susu sapi perah adalah pemberian pakan yaitu berupa pakan hijauan dan konsentrat sehingga besar kecilnya jumlah pemberian pakan pada sapi perah akan sangat berpengaruh terhadap jumlah susu yang dihasilkan. Sehingga perlunya peningkatan produksi hijauan pakan serta sumber lain yang dapat meningkatkan produksi susu seperti tanaman bangun-bangun (Coleus amboinicus, Lour). Berdasarkan hal diatas maka diangkatlah judul Pemanfaatan pupuk organik terhadap produksi tanaman bangun-bangun (Coleus amboinicus, Lour).

\section{Tujuan dan Manfaat}

Kegiatan ini bertujuan untuk memberikan pengetahuan dan keterampilan kepada peternak tentang penanaman tanaman bangun-bangun (Coleus amboinicus, Lour) dengan menggunakan pupuk organik untuk menggantikan fungsi dari pupuk buatan sehingga biaya pupuk menjadi lebih murah dan peningkatan terhadap produksi tanaman bangun-bangun (Coleus amboinicus, Lour). Manfaat dari kegiatan ini adalah untuk membantu peternak dalam mengembangkan salah satu tanaman yang dapat meningkatkan produksi susu melalui pemberian tepung bangun-bangun dalam permen jilat.

\section{METODE PENGABDIAN MASYARAKAT}

1. Memberikan ceramah dan pengarahan tentang manfaat daun bangun-bangun. 
2. Memberi dan mengajarkan bagaimana budidaya tanaman bangun-bangun dan langsung membuat demplot dalam penanaman bangun-bangun yang diberi pupuk organik

3. Memberi binaan dan bimbingan langsung ke lapangan.

4. Mengevaluasi hasil-hasil yang dicapai selama pelaksanaan dan pembinaan berlangsung.

\section{HASIL DAN PEMBAHASAN}

\section{Produksi Tanaman Bangun-bangun ( Coleus amboinicus, L)}

\section{Tinggi Tanaman}

Berdasarkan hasil evaluasi didapatkan informasi tinggi tanaman bangun-bangun (Coleus amboinicus, L) yang ditanam pada lahan kelompok tani/ ternak Lembu Alam Serambi, dengan jarak tanam adalah $30 \times 40$ $\mathrm{cm}$ dan tinggi tanaman diukur pada akhir panen yaitu umur 90 hari setelah tanam dilihat pada Tabel 2. Tanaman bangun-bangun (Coleus amboinicus, Lour) dijadikan 3 demplot dengan perlakuan A1 (tanpa pupuk kompos/NPK $550 \mathrm{~kg} / \mathrm{ha}$ ), A2 (pupuk kompos 10 ton /ha) dan A3 (pupuk kompos 12 ton/ha). Dari hasil pengukuran tinggi tanaman bangunbangun (Coleus amboinicus, Lour) didapatkan bahwa pemberian pupuk kompos 12 ton/ha lebih tinggi dibandingkan dengan 10 ton/ha sedangkan tanaman bangun-bangun (Coleus amboinicus, Lour) yang dipupuk dengan pupuk an organik (NPK) lebih rendah dibandingkan dengan tanaman bangunbangun (Coleus amboinicus, Lour) yang menggunakan pupuk kompos 10 ton / ha, hal ini berarti pupuk kompos dapat menggantikan pemakaian pupuk an organik (NPK). Tingginya tanaman pada A3 merupakan perlakuan pemupukan dengan dosis yang paling tinggi sehingga ketersediaan unsur haranya lebih banyak. Seperti yang dijelaskan Siregar, Fati dan Wahono (2013), bahwa pupuk organik bersifat bulky dengan kandungan hara makro dan mikro rendah sehingga perlu diberikan dalam jumlah banyak. Manfaat utama pupuk organik adalah dapat memperbaiki kesuburan kimia, fisik dan biologis tanah, selain sebagai sumber hara bagi tanaman. Tinggi tanaman yang dihasilkan berkisar antara 24,75 cm - 34 $\mathrm{cm}$, kisaran ini masih dalam kisaran yang dikemukakan oleh ARCBC (2004) cit Rumetor (2008) yaitu $30 \mathrm{~cm}-45 \mathrm{~cm}$. Sedangkan dari hasil penelitian Rumetor (2008), tinggi tanaman bangun-bangun yang ditanam pada areal penanaman yang mendapatkan naungan sebesar 40-60\%, merupakan lahan yang sebagian sudah ditanam kaliandra, tinggi tanaman mencapai $50 \mathrm{~cm}-80 \mathrm{~cm}$, sedangan pada tanaman Coleus amboinicus Lour yang arealnya tidak ada naungan tinggi tanaman hanya mencapai $\pm 30 \mathrm{~cm}$. Hasil tinggi tanaman demplot Coleus amboinicus Lour lebih rendah dari hasil penelitian oleh Urnemi (2002) cit Rumetor (2008), yang mendapatkan bahwa pada penanaman Coleus amboinicus Lour dengan naungan 50\% menghasilkan tinggi tanaman 59,55 $\mathrm{cm}$ dan naungan $75 \%$ menghasilkan tinggi tanaman 90,64\% dan lebih tinggi lagi tanpa naungan, yang hanya mencapai 38,18 $\mathrm{cm}$. Bervariasinya tinggi tanaman bangunbangun yang dihasilkan tersebut tidak terlepas dari nutrisi yang didapat tanaman tersebut. Lebih lanjut Munawar (2011) cit Siregar et al. (2013) menyatakan bahwa nutrisi tanaman mengacu kepada bagaimana tanaman mendapatkan, menyebarkan, dan menggunakan unsurunsur hara dalam berbagai proses dan reaksi yang berlangsung di dalam tanaman bagi pertumbuhan dan perkembangan tanaman.

Tabel 1. Pengaruh pemberian kompos kotoran sapi terhadap tinggi tanaman

\begin{tabular}{|l|c|}
\hline \multicolumn{1}{|c|}{ Perlakuan } & $\begin{array}{c}\text { Tinggi tanaman } \\
\text { umur 3 bulan } \\
(\mathrm{cm})\end{array}$ \\
\hline A1( Tanpakompos) & 24.75 \\
\hline $\begin{array}{l}\text { A2 ( Pupuk kompos } \\
10 \text { ton/Ha) }\end{array}$ & 26.5 \\
\hline $\begin{array}{l}\text { A3 (Pupuk kompos } \\
12 \text { ton/Ha) }\end{array}$ & 34.0 \\
\hline
\end{tabular}


Pupuk kompos disamping dapat menambah unsur hara di dalam tanah juga dapat memperbaiki struktur tanah, memperbaiki humus dan mendorong kehidupan jasad renik tanah. Seperti yang dinyatakan Setyamidjaya (1986), bahwa kandungan $\mathrm{N}, \mathrm{P}$ dan $\mathrm{K}$ pada setiap pupuk mempunyai peranan dalam merangsang pertumbuhaan vegetatif serta memacu pertumbuhan jaringan terutama tinggi tanaman, jumlah anakan dan daun.

\section{Produksi tanaman bangun-bangun (Coleus amboinicus Lour)}

Berdasarkan hasil evaluasi didapatkan informasi produksi tanaman bangun-bangun (Coleus amboinicus, L) yang ditanam pada lahan kelompok tani/ ternak Lembu Alam Serambi, yang dipanen pada umur 3 bulan setelah tanam dilihat pada Tabel 3. Tanaman bangun-bangun (Coleus amboinicus, L) dijadikan 3 demplot dengan perlakuan A1 (tanpa pupuk kompos/NPK $550 \mathrm{~kg} / \mathrm{ha}$ ), A2 (pupuk kompos 10 ton /ha) dan A3 (pupuk kompos 12 ton/ha). Dari hasil panen per rumpun tanaman bangun-bangun (Coleus amboinicus, L) tersebut didapatkan bahwa pemberian pupuk kompos 12 ton/ha produksinya lebih tinggi dibandingkan dengan 10 ton/ha sedangkan tanaman bangun-bangun (Coleus amboinicus, L) yang dipupuk dengan pupuk an organik (NPK) produksinya lebih rendah dibandingkan dengan tanaman bangunbangun (Coleus amboinicus, L) yang menggunakan pupuk kompos 10 ton / ha, hal ini berarti pupuk kompos dapat menggantikan pemakaian pupuk an organik (NPK).

Hasil penelitian Rumetor (2008), produksi tanaman bangun-bangun (Coleus amboinicus, Lour) per rumpunnya adalah berkisar 300-350 gr, hasil yang didapatkan dari informasi di lapangan pada demplot pengabdian ini lebih rendah yaitu berkisar $142,25 \mathrm{gr}-224,375$ gr per rumpun. Hal ini di pengaruhi oleh kondisi lahan tempat penanaman, kandungan hara tanah, dan adanya naungan bagi tanaman bangun-bangun (Coleus amboinicus, Lour). Tabel 2 juga memperlihatkan bahwa hasil produksi per hektar tanaman bangun-bangun (Coleus amboinicus, Lour). Tanaman yang dipupuk dengan pupuk kompos 12 ton/ha, produksi segar lebih tinggi dibandingkan dengan pupuk NPK dan pupuk kompos 10 ton/ha. Hasil ini lebih rendah dari yang didapatkan Rumetor (2008), produksi tanaman bangun-bangun
(Coleus amboinicus, Lour) umur 3 bulan produksinya per ha adalah $7500 \mathrm{~kg}$ bobot segar.

Tabel 2. Pengaruh pemberian kompos kotoran sapi terhadap produksi tanaman Coleus ambonicus Lour

\begin{tabular}{|l|c|c|}
\hline Perlakuan & $\begin{array}{l}\text { Produksi } \\
\text { segar per } \\
\text { rumpun umur } \\
\text { 3 bulan (gr) } \\
\text { /rumpun }\end{array}$ & $\begin{array}{l}\text { Produksi } \\
\text { segar per Ha } \\
\text { (kg) }\end{array}$ \\
\hline $\begin{array}{l}\text { A1 ( Tanpa } \\
\text { kompos) }\end{array}$ & 142,25 & 4720.62 \\
\hline $\begin{array}{l}\text { A2 ( Pupuk } \\
\text { kompos 10 } \\
\text { ton/Ha) }\end{array}$ & 168,75 & 4845,12 \\
\hline $\begin{array}{l}\text { A3 (Pupuk } \\
\text { kompos 12 } \\
\text { ton/Ha) }\end{array}$ & 224,375 & 7449,25 \\
\hline
\end{tabular}

Kesimpulan

Dari kegiatan pengabdian kepada masyarakat yang telah dilakukan di kelompok ternak Permato Mudo Nagari dan Lembu Alam Serambi, di kelurahan Silaing bawah, Kecamatan Padang Panjang Barat Kotamadya Padang Panjang, terhadap produksi tanaman bangunbangun, dapat diambil kesimpulan sebagai berikut :

1. Pengetahuan masyarakat peternak tentang budidaya tanaman sudah cukup baik

2. Penerapan tekhnologi pupuk kompos dapat meningkatkan tinggi tanaman dan produksi tanaman dibandingkan menggunakan pupuk NPK. Penggunaan pupuk kompos $12 \mathrm{~kg} / \mathrm{Ha}$ dapat meningkatkan tinggi dan produksi tanaman bangun-bangun dibandingkan dengan pemberian pupuk kompos 10 ton/Ha dengan pupuk NPK.

\section{Saran}

Berdasarkan hasil kegiatan ini, terbukti bahwa teknologi pemanfaatan pupuk kompos sangat bermanfaat bagi peternak sapi perah dari kelompok yang 
dibina karena dapat menggantikan pupuk buatan. Oleh karena itu diharapkan Pemda Padang Panjang dapat menyebarluaskan teknologi ini ke seluruh peternak sapi perah yang ada di Padang Panjang.

\section{REFERENSI}

Damanik. R., Damanik, M. L. Wahguist and Wattanapenpaibon. 2006. Lasctogogue effects bangun-bangun, a Bataknese tradiotional cuisine. APJCN; 15 (2) : 267 274.

Batubara I, V. Mirtaningtyas, A. Setyawan, A. Haryati dan I. Nurmala. 2004 Angka Unsur-unsur penting ( $\mathrm{P}, \mathrm{K}, \mathrm{Ca}, \mathrm{Mg}$ dan $\mathrm{Fe}$ ) flavonoid daun torbangun (Coleus ambo- inicus Lour) sebagai gambaran daun torbangun dalam kesehatan masyarakat. Pusat Studi Biofarmaka LPPM IPB.

Buchanan-Smith, J., L.L. Berger, C. Ferrell, D. G. Fox, M. Galyean, D.P. Hutcheson, T.J. Kloppensein and J. Spears. 2000. Nutrient Requirement of beef cattle. Seventh revised Edition. National Academy Press, Washington, DC.

(Depkes) Departemen Kesehatan, 2005. Botani, Sinonim Nama umum dan Nama Dagang Daun Bangun bangun, Jakarta; Depkes (Terhubung berkala). http://www,iptek.apjii.or.id ( 5 April 2005).

Hartadi, H., S. Reksohadiprodjo dan A. D. Tilman. 1995. Tabel komposisi pakan untuk Indonesia, Gajah Mada press, Yogyakarta

Lawrence M, Naiyana, Damanik MRM. 2005. Modified nutraceutical composition Australia: Freehills patent and trademark attorneys, Melbourne. http://www.wipo.int/petdb. didownload 20 Mei 2013.

Piliang. 2000. Nutrisi mineral, IPB Bogor, Edisi ke 3. IPB press, Bogor..

Rumetor., S.D. 2008. Suplementasi daun bangun-bangun (( Coleus amboinicus, Lour) dan zinc-vitamin $\mathrm{E}$ dalam ransum untuk memperbaiki metabolisme dan produksi susu kambing peranakan Etawah (Disertasi) Bogor. Pascasarjana, Institut Pertanian Bogor.
Santosa, Ch. M. 2001. Khasiat konsumsi dau bangun-bangun (Coleus amboinicus, L) sebagai pelancar sekresi air susu ibu menyusui dan memacu petumbuhan bayi. Tesis. Program Pascasarjana, IPB Bogor.

Silitonga, M. 1993. Efek laktagogum daun jinten (Coleus amboinicus, L) pada tikus laktasi. Program pascasarjana, Institut Pertanian Bogor.

Siregar, R., N. Fati dan S. Wahono. 2013. Potensi dan karakterisasi daun bangunbangun (coleus amboinicus 1.) Daerah Sumatera Barat dan pemanfaatannya dalam meningkatkan reproduksi ternak kambing peranakan etawah. Laporan Penelitian. Tidak diterbitkan. Politekhnik Pertanian Negeri Payakumbuh.

Sudono, A., F. Rosdiana dan B. S. Setiawan. 2003. Beternak Sapi Perah Secara Intensif. Penerbit PT. AgroMedia Pustaka, Jakarta.

Tarmidi, H.A.R. 2009. Kajian fungsi mineral seng $(\mathrm{ZN})$ bagi ternak. Fakultas Peternakan Universitas Padjajaran, Bandung.

Weaning, W. 2007. Penambahan daun bangunbangun ( Coleus amboinicus, Lour) dalam ransum pengaruhnya terhadap sifat reproduksi dan produksi Air susu Mencit putih (Mus musculus Albinus). Skripsi. Jurusan Ilmu Produksi Ternak. Fakultas Peternakan. Institut Pertanian Bogor, Bogor. 
